\title{
How logrolling can explain the failure of the government coalition in Brazil*
}

\author{
Márcio André de Carvalho**
}

SumMARY: 1. Introduction; 2. Opening remarks; 3. Logrolling; 4. Conclusion and future research.

SuMÁRIO: 1. Introdução; 2. Considerações iniciais; 3. Logrolling; 4. Conclusão e pesquisas futuras.

KEY WORDS : logrolling; trade of votes; strategic voting; government coalition; Brazilian House of Representatives; constitutional amendment in Brazil; public choice; rational choice theory.

Palavras-chave: logrolling; troca de votos; votos estratégicos; bancada governista; coalizão; Câmara dos Deputados; emendas à Constituição; governo FHC; public choice; teoria da escolha racional.

This article presents an analysis of the behavior of federal representatives in the Brazilian House of Representatives between 1995 and 1998, when a series of constitutional amendments were presented by the president to be voted on by Congress. The objective is to show that the lack of a stable government coalition resulted in costs to society that were not anticipated by the government. The study argues that a logroll — a trade of votes — was the strategy used by the government in order to guarantee the number of votes necessary to approve the amendments. This strategy created a vicious system in which representatives would only vote with the government if they had benefits in return.

\section{Como o logrolling pode explicar o fracasso da coalizão governamental no Brasil}

Este artigo apresenta uma análise do comportamento dos deputados federais brasileiros na Câmara entre 1995 e 1998, quando várias emendas cons-

* Article received in Nov. 2005 and accepted in June 2006.

** Professor at Ebape/FGV, PhD and MPA from The State University of New York at Albany; MPS from UnB. Address: Praia de Botafogo, 190, sala 504 - CEP 22250-900, Rio de Janeiro, RJ, Brazil. E-mail: macarvalho@fgv.br. 
titucionais foram apresentadas pelo presidente Fernando Henrique Cardoso. O objetivo é mostrar que a falta de uma coalizão governamental (ou bloco governamental) estável resultou em custos para a sociedade que não foram previstos pelo governo. O argumento usado é que o logrolling - troca estratégica de votos - foi a estratégia utilizada pelo governo para garantir o número de votos necessários para aprovar as emendas. Assim, na tentativa de se garantir o número mínimo de votos, o governo criou um sistema no qual os deputados apenas votariam com ele se tivessem algum tipo de retorno em troca dos seus votos.

\section{Introduction}

This article presents an analysis of the behavior of federal representatives in the Brazilian Congress between 1995 and 1998, when a series of constitutional amendments were presented by the president to be voted on by Congress. The objective is to show that the lack of a stable governmental coalition resulted in costs to society that were not anticipated by the government.

The argument used in this study is that a logroll — a trade of votes was the strategy used by the government in order to guarantee the number of votes necessary to approve the amendments. This strategy created a vicious system in which representatives would only vote with the government when they had benefits in return.

This article is divided into four parts, including this introduction. The next part summarizes the problem to be studied. The following part defines logrolling and presents the model that describes the logrolling process in Brazil. The last part has the conclusions and suggestions for further research in this topic.

\section{Opening remarks}

In 1995 the former Finance Secretary Fernando Henrique Cardoso became president of Brazil. ${ }^{1}$ His major platform during the 1994 campaign was that the country's economic and social development would only be achieved with profound reforms in the Brazilian economic and fiscal structures.

\footnotetext{
${ }^{1}$ Before being elected president, Cardoso was the finance minister who dropped the country's inflation from about $2,000 \%$ a year to less than $2 \%$ a year in 1994 . He is currently in his second term as a president. 
One of Cardoso's first acts as president was to send Congress a series of constitutional amendments that would start the structural changes that he proposed during his campaign. In Brazil, a constitutional amendment is voted on first by the House of Representatives and, if approved by 3/5 of the members in two roll call votes, it goes to the Senate for approval in a similar procedure. If the amendment is approved by both houses, it becomes part of the Constitution.

When first presented in Congress, the constitutional amendments received considerable party support since they were seen by political analysts and by politicians as necessary to the economic and social development of the country. However, a close analysis showed that some of the amendments would change a series of popular benefits such as the Brazilian social security and would privatize some governmental enterprises. Therefore, these changes could jeopardize Congressional members in future elections, lessening the strong initial support that the amendments had received (Arnold, 1992).

Other factors that had strong influence against the amendments were the number of political parties in Congress and the lack of party fidelity. At that time, there were 20 political parties in the House of Representatives, ranging from one to 110 members. In order to approve a constitutional amendment, 308 votes from the pool of 513 representatives were necessary. Inside each party, a leader suggested to the members how to vote, but the representatives were free to vote as they wanted without formal penalties if they did not follow the leader's suggestion. ${ }^{2}$

Due to these three major reasons, the recently elected president was facing a series of obstacles to approve the amendments. Figure 1 shows the votes in favor and against the president's proposed constitutional amendments for the period 1995 to 1998 in the House of Representatives. Despite the approval of many of the amendments, the votes in favor and against the government ${ }^{3}$ oscillated substantially in the period, indicating the presence of a governmental coalition that did not have a constant number of representatives. If this coalition had had the 308 necessary votes to approve the amendments (dotted line on figure 1), the oscillations would have assumed lower amplitude. Therefore, the graph indicates that during the four years under consideration, representatives joined this coalition and voted with the government depending on the benefits that they could extract from the coalition.

\footnotetext{
2 This scenario is still the same.

${ }^{3}$ In this paper, the president and the government will be used interchangeably.
} 
Figure 1

Votes in favor and against the government

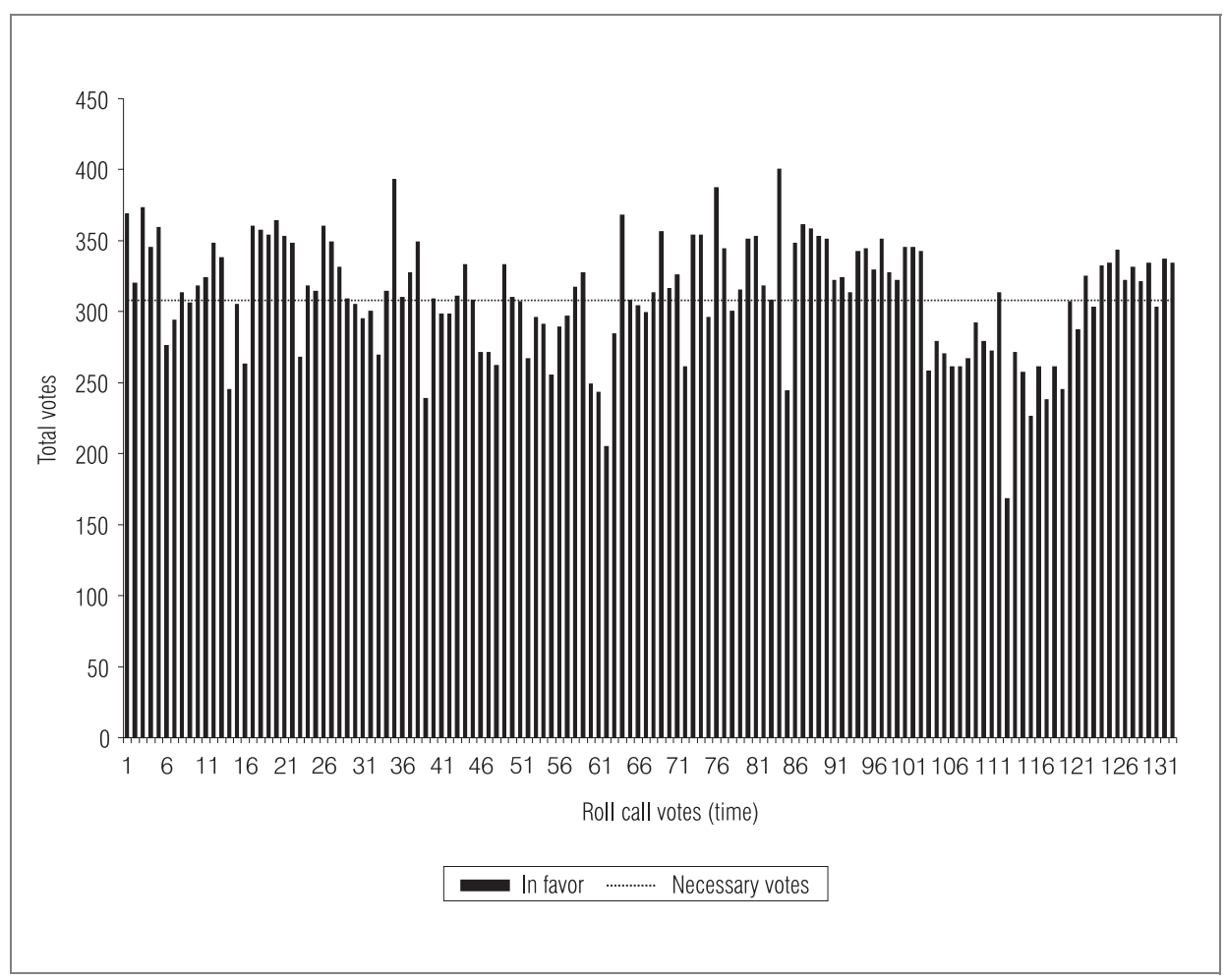

The movement of representatives in and out of the governmental coalition indicate that logrolling was the strategy used by the government in order to have the necessary number votes to approve the constitutional amendments proposed by the president. Therefore, during the period 1995-98, members of the House of Representatives could have been part of three groups: a stable governmental coalition - not large enough to approve the constitutional amendments; the opposition that would always vote against the government; or a group that would oscillate between government and opposition, depending on the benefits that it could trade - logroll — with the government.

As a result, the final size of the governmental coalition or that of the opposition group would be the core of representatives of each, plus the members of the oscillation group that would join each one of the groups (red and blue areas in the circles in figure 2), plus (and minus) some dissidents of each core that could for some very specific reasons change their "natural" behavior and vote with the other side (doted line in figure 2). 
Figure 2

\section{Representative vote choice in Brazil}

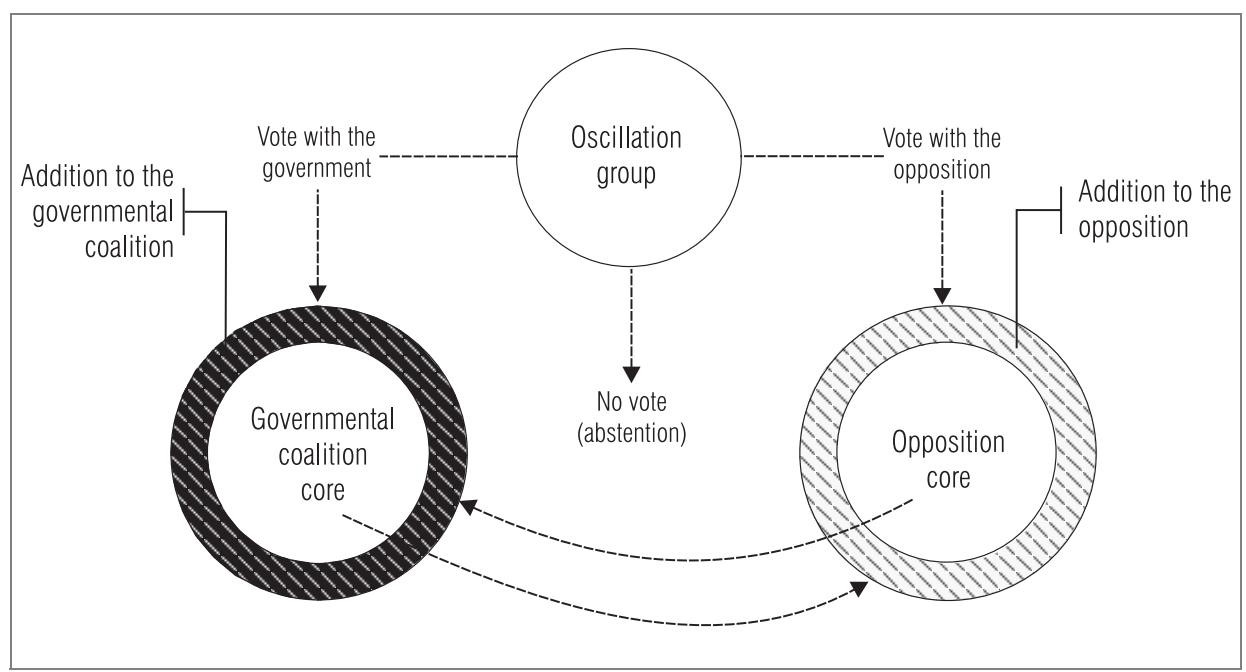

This article suggests that the failure of the government to form a constant governmental coalition large enough to approve the proposed changes in the Constitution resulted in the process of logrolling with representatives, incurring in an unexpected high cost for the government, and consequently for society.

\section{Logrolling}

Logrolling can be simply defined as a trade of votes with a specific purpose, or the buying and selling of individual votes. This trade can involve only endogenous factors in the environment where the trade is happening, for example, representatives trading votes in support of their bills (Mayer and Canon, 1999), or it can have an exogenous factor influencing the trade, as in the president influencing the way representatives vote or behave inside the House (Sullivan, 1990; Marchi and Sullivan, 1997; Faad, 2000; Pereira and Mueller, 2002).

Matthews (1999:211) mentions the common reciprocity among senators as an ordinary practice in the U.S. Senate. "The most important aspect of this pattern of reciprocity is, no doubt, the trading of votes." The author goes beyond the simple support for bills and mentions that the implicit bargaining 
in the Senate explains much of the behavior of senators. "The spirit of reciprocity results in much, if not most, of the senators' actual power not being exercised. If a senator does push his formal powers to the limit, he has broken the implicit bargain and can expect, not cooperation from his colleagues, but only retaliation in kind" (Matthews, 1999:212). In the same direction, Asher (1999) mentions the importance of knowing the implicit rules of logrolling. He classifies the trade rules as important as the formal rules inside the legislature.

Weisberg, Heberlig and Campoli (1999) assume that members of Congress can seek two behaviors. The first would maximize his/her chances of reelection. The second would post the legislator as interested in passing good public policies. Either way, a member of Congress would use logrolling as a tool to maximize the chances of passing a bill. The logrolling process can involve more than single individuals. It can also include parties that will trade their support to obtain certain goal (Davidson and Oleszek, 2000).

Logrolling takes into consideration the individual preferences and their intensity in a single decision-making process. Let us consider table 1 as an example. Three voters A, B and C, have different preferences over two issues, $\mathrm{X}$ and $\mathrm{Y}$.

\begin{tabular}{|ccc|}
\hline \multicolumn{3}{c|}{ Table 1 } \\
& Logrolling process \\
\hline \multirow{2}{*}{ Voters } & \multicolumn{2}{c}{ Issues } \\
\cline { 2 - 3 } & $\mathrm{X}$ & Y \\
\hline A & -2 & -2 \\
B & 5 & -2 \\
C & -2 & 5 \\
\hline
\end{tabular}

For instance, voter $\mathrm{A}$ is indifferent between $\mathrm{X}$ and $\mathrm{Y}$ because he is going to lose 2 utility points if he approves any of the two issues. Voter B prefers $\mathrm{X}$ than $\mathrm{Y}(\mathrm{X}>\mathrm{Y})$ and voter $\mathrm{C}$ prefers $\mathrm{Y}$ rather than $\mathrm{X}(\mathrm{Y}>\mathrm{X})$. If the three voters had to choose under the majority rule, a deadlock would be created and none of the two issues would be approved. However, if voters B and C are allowed to trade votes, B can vote for issue $\mathrm{Y}$, even if he does not like it, in exchange for a vote of $\mathrm{C}$ for $\mathrm{X}$ in the future: 
The trade between B and C can be said to have improved the welfare of the community of three voters (...). Without trading, the majority would rule over the relatively more intense minority on each issue. Through vote trading, these minorities express the intensity of their preferences, just as trading in private goods does, and improve the total welfare change of the community. With trading, there is a net gain of 2 for the community.

(Mueller, 1997:83)

An advance in the trade model described above is presented in table 2. Let us assume that $\mathrm{A}, \mathrm{B}$ and $\mathrm{C}$ are three groups that could benefit from public policies. Policy X will only benefit group B and policy Y would only benefit group C. The benefit gain for the group is 7 and the cost for the whole society in adopting a policy is 6 - the 6 will be shared among the three groups. So, if $\mathrm{B}$ and $\mathrm{C}$ trade votes, policies $\mathrm{X}$ and $\mathrm{Y}$ will be approved. Group A will have a net gain of $-4[(-2)+(-2)]$, since it does not have any benefit from the policies but it shares the costs. B will have a gain of $3[(-2)+(7)+(-2)]$ and the same with $C[(-2)+(-2)+(7)]$.

\begin{tabular}{|c|c|c|c|c|c|c|}
\hline \multirow{3}{*}{$\begin{array}{c}\text { Winning } \\
\text { pair }\end{array}$} & \multirow{3}{*}{$\begin{array}{l}\text { Losing } \\
\text { pair }\end{array}$} & \multicolumn{3}{|c|}{$\begin{array}{c}\text { Table } 2 \\
\text { Logrolling process II }\end{array}$} & & \\
\hline & & \multirow{2}{*}{$\begin{array}{l}\text { Trading } \\
\text { votes }\end{array}$} & \multicolumn{4}{|c|}{ Utilities } \\
\hline & & & A & B & C & $\begin{array}{c}\text { Society's } \\
\text { gain }\end{array}$ \\
\hline$X, Y$ & $\sim X, \sim Y$ & $\mathrm{~B}$ and $\mathrm{C}$ & -4 & 3 & 3 & 2 \\
\hline$X, \sim Y$ & $\sim X, Y$ & $A$ and $B$ & -2 & 5 & -2 & 1 \\
\hline$\sim X, \sim Y$ & $X, Y$ & $A$ and $C$ & 0 & 0 & 0 & 0 \\
\hline
\end{tabular}

In these three cases, the gains for society (sum of the individual utilities for each group) would be positive. However, as Mueller (1997) indicates, changing the values of gains and losses for each one of the groups can lead to a case where one or more groups could benefit from a policy, but social welfare will be worsened.

The proposed model that describes the logrolling process in the Brazilian House of Representatives between 1995 and 1998 was based on many of 
the assumptions that Sullivan (1990) and Marchi and Sullivan (1997) used in their studies about the bargaining process between the president and the members of Congress in the United States.

The following are the assumptions for the model used in this article:

v there are two main groups of actors in the system: the representatives and the president (government). While voting, representatives can be for or against the government;

v representatives try to maximize their chances of reelection. Therefore, they will do anything necessary to bring more benefits for their constituencies (Arnold, 1992);

v members of the House and the president have imperfect information. The president will bargain and try to form the coalition to win, but, since the vote is secret, the president and other members of the House do not know the size of the coalition and who its members are until the final results are disclosed;

v the president will exchange political and financial support for votes. The political support for a single representative can be shown as presidential actions to approve a bill in which the representative has interest, or future campaign support. The financial support can be shown through pork-barrel policies. ${ }^{4}$ Both political and financial support will incur in costs for the government that will be aggregated in the model;

v legislators are presumed to vote strategically. They will not necessarily vote with their preferences.

Much is said in the public choice literature about the need for a minimum winning coalition, or that coalitions will almost naturally be built in a number just large enough to win (Shepsle, 1974; Koehler, 1975; Bickers and Stein, 1997). Under the majority rule, the minimum winning coalition would have $(\mathrm{N} / 2)+1$ of the votes, and in a $3 / 5$ rule $(3 \mathrm{~N} / 5)+1$ of the votes, where $\mathrm{N}$ is equal to the number of voters.

\footnotetext{
${ }^{4}$ In Brazil, an important tool that the president can use to negotiate votes is this necessary approval of the representatives' single amendments for the federal budget. While in Congress, members of the House and the Senate can present amendments for the federal budget. Most of these amendments are parochial and benefit the districts where the members of Congress were elected. Therefore, after the federal budget is approved, the government has to consent to those amendments. The president can use this constitutional tool to negotiate with Congress members and get the votes for his proposals. 
Figure 3

\section{Optimum (minimum) winning coalition in the Brazilian House of Representatives}

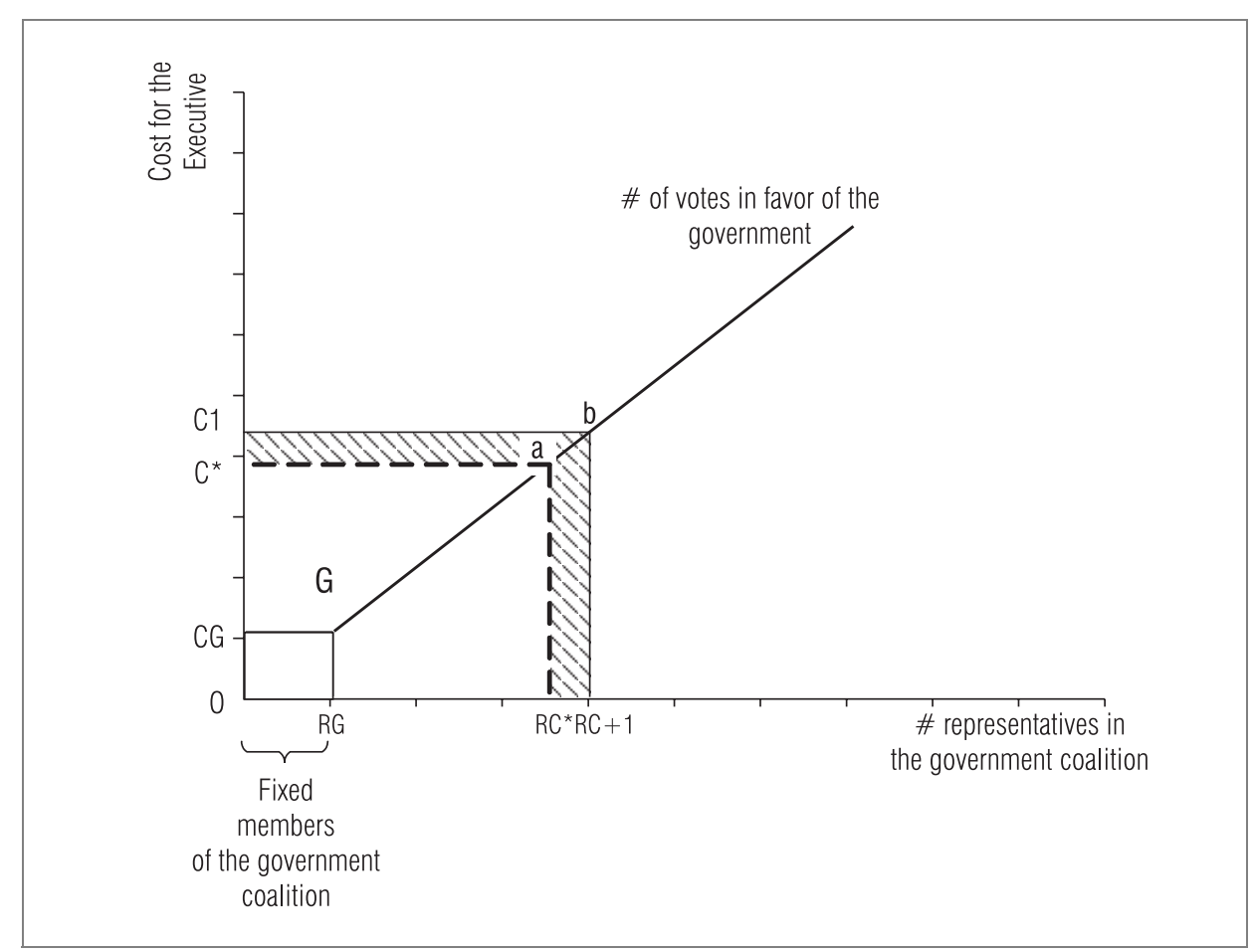

Figure 3 demonstrates the optimum winning coalition for the Brazilian House of Representatives. The x-axis shows the number of representatives in the government coalition and the y-axis has the aggregate cost (political and financial costs) of the votes for the government. As mentioned, the government coalition will have a constant number or representatives that, for the sake of simplicity, will be considered that from the president's party. These stable members are represented as RG in the x-axis, and the cost of this group - a fixed cost for the government - will be the area O-RG-G-CG. The point $\mathrm{RC} *$ represents the necessary number of representatives that the coalition needs for approving an amendment that interests the government. Therefore, the area O-RC*-a-C* represents the expected cost for the government to approve a constitutional amendment. In fact, one can say that this cost will be translated into future gains for society, since it is assumed that the amend- 
ment being voted on will fix a structural problem in the country's economy. An extra representative in the government coalition is represented by $\mathrm{RC}+1$. The marginal cost of this extra representative will be the shaded area. Therefore, the model implies that the marginal cost of representatives entering the coalition will, most of the time, increase.

As the government does not have perfect information about how many representatives besides those from the stable coalition will join its coalition, a large number of logrolling can happen simultaneously in trying to guarantee the necessary number of votes to approve the amendment.

Figure 4

The cost of a large government coalition in the Brazilian House of Representatives

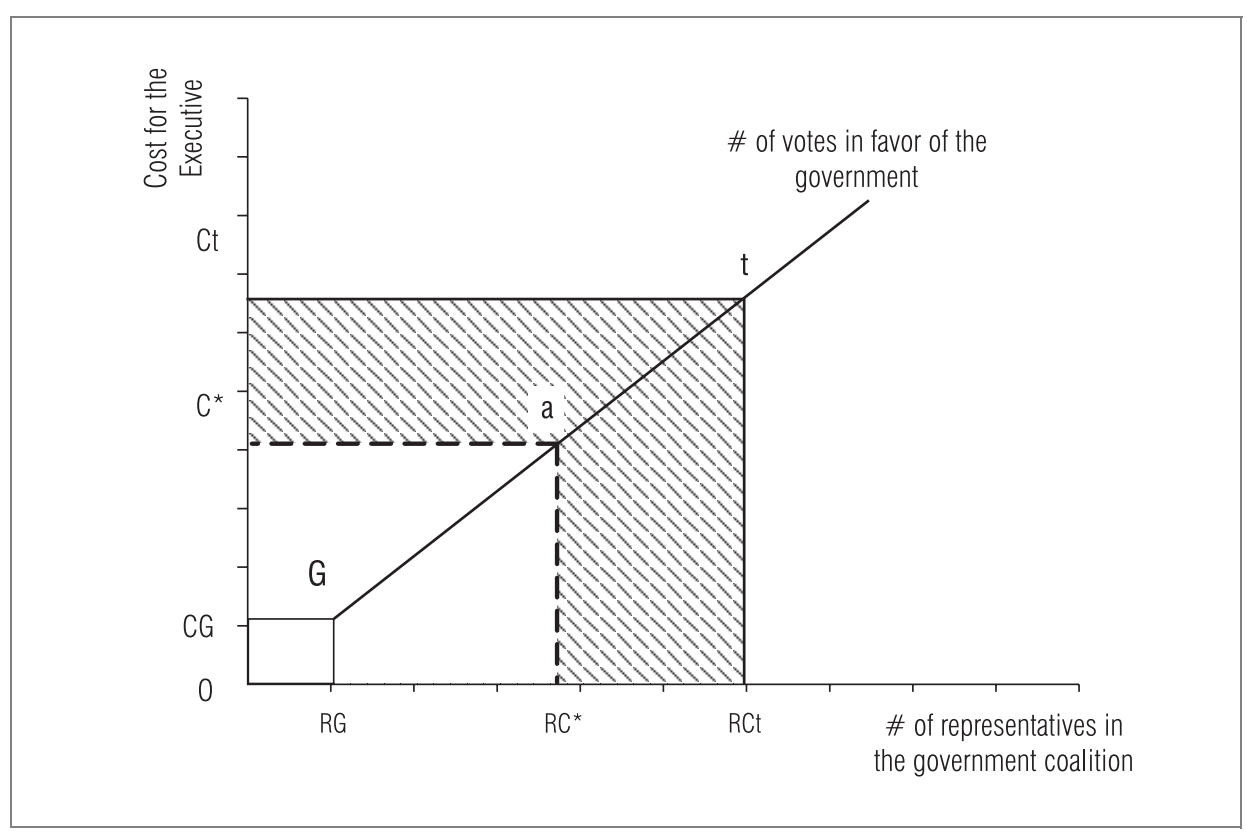

Figure 4 shows a consequence of the lack of perfect information in the logrolling game. When the result of the voting process was announced, the government realized that the number of votes in its favor (RCt) was much higher than the number of votes necessary to approve the amendment (RC*). Consequently, the total cost for this specific amendment - area O-RCt-t-Ct 
- was much higher than expected. The difference between the two areas, shown in the graph as the shadow area, is the extra cost that society has to pay due to the negotiations to approve the amendment.

In an empirical study, Faad (2000) showed that, in order to approve one of the Constitutional amendments, the government traded individually with representatives in the Brazilian House of Representatives. Among the benefits that representatives received after the approval of the amendment were subsidies to increase wine exports from one region, monetary resources to build roads and highways in different parts of the country, and political appointments for Federal and State positions.

One can say that these benefits were not costs, but local improvements that representatives had to bargain for in the Congress. In fact, in part that assumption is true. However, they were considered costs because they diverted resources from Federal programs to local necessities, thus benefiting a much smaller number of people. Since the government has limited resources, in order to pay back representatives for their vote it has to reallocate these resources.

What if the government does not pay back the representatives who joined the coalition at the last minute to approve a Constitutional amendment? In this case, those representatives will respond the next time the government needs them. The group that did not receive the bargained benefits will vote against the government or will decline to vote. Those representatives are signaling that if they do not receive their payment, they will not join the government coalition. This could it be another explanation for the great oscillation from one roll call vote to another on figure 1.

Figure 5 demonstrates what would happen if the government lost an amendment roll call on the House of Representatives. Again, RC* would be the optimum coalition, or the 308 necessary votes for passing the amendment. RL would be the number of representatives that voted with the government. $\mathrm{RL}$ is smaller than $\mathrm{RC}^{*}$, consequently the government failed to approve the amendment.

The cost of failing would be the area O-RC*-a-C*, which is the original expected cost for the government and, as seen, a cost for society since it represents some failure that has to be fixed by this amendment, plus the area O-RLL-CL, which represents the logrolling with the representatives who voted with the government. The question that could arise is: Why should the government still pay back the representatives who voted with it if the amendment was not approved? The government should still pay those representatives to avoid future failures in approving other amendments or bills. In this case, the government is signaling to other representatives that it is a trusty source that honors its debts. The losing scenario is the worst one for the president and for society, since it is the one were losses are maximized. 
Figure 5

The cost of a governmental loss

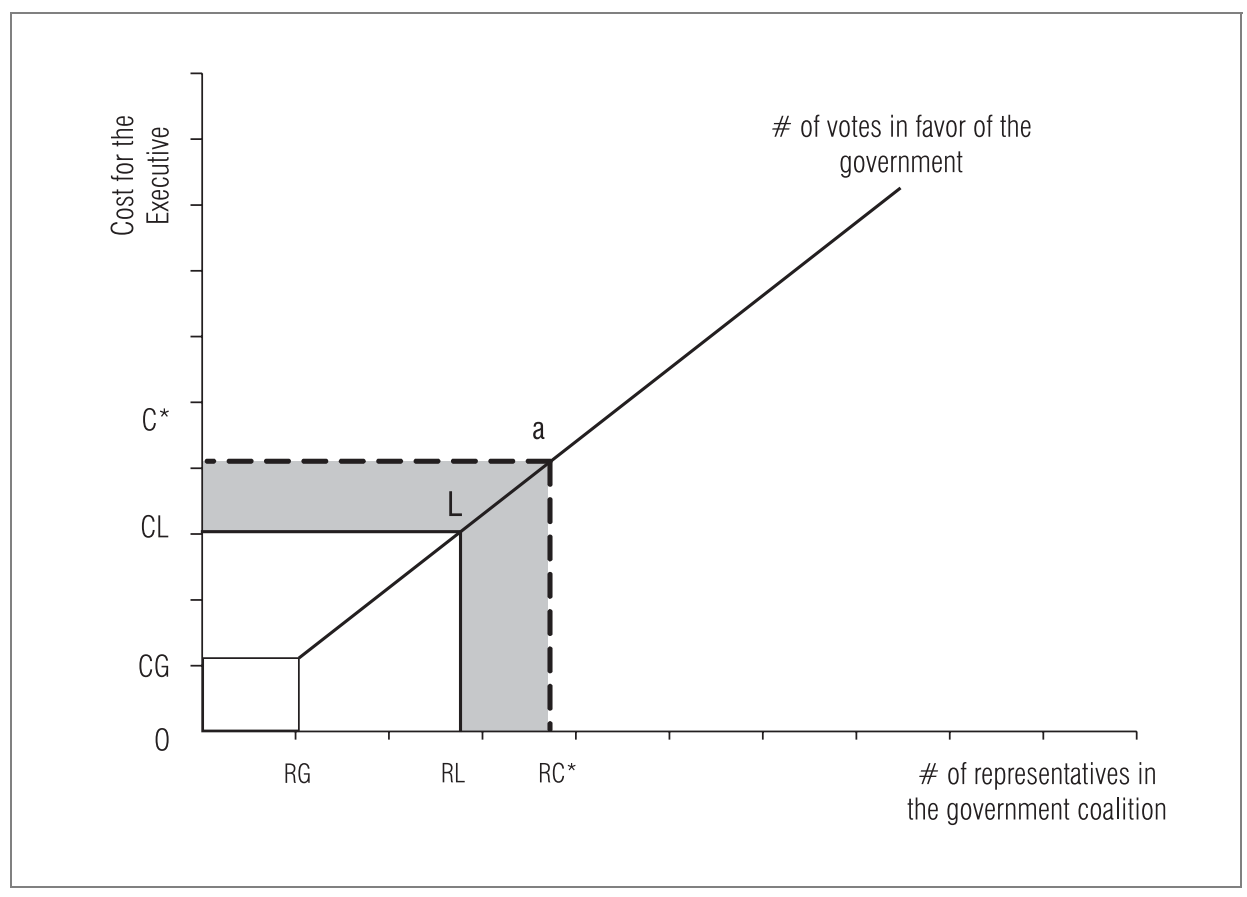

The cost of logrolling and consequently building the government coalition was not the same for all the amendments voted. The first representatives that joined the coalition were those who determined the slope of the graph. If the constitutional amendment was not easy to approve, those who joined the coalition early would demand a larger price and consequently the marginal cost of new members would also be higher. Figure 6 exemplifies this argument. The cost of one extra representative in this case would be much higher than in the other examples, and consequently the cost for society would also increase

On the other hand, an amendment that was easy to approve - one strongly demanded by society, for instance - would have a smaller slope, as shown in figure 7. In an extreme case the slope of the graph could be zero for those policies that have to be approved by the House or that demand consensus. 
Figure 6

\section{Example of a high cost amendment}

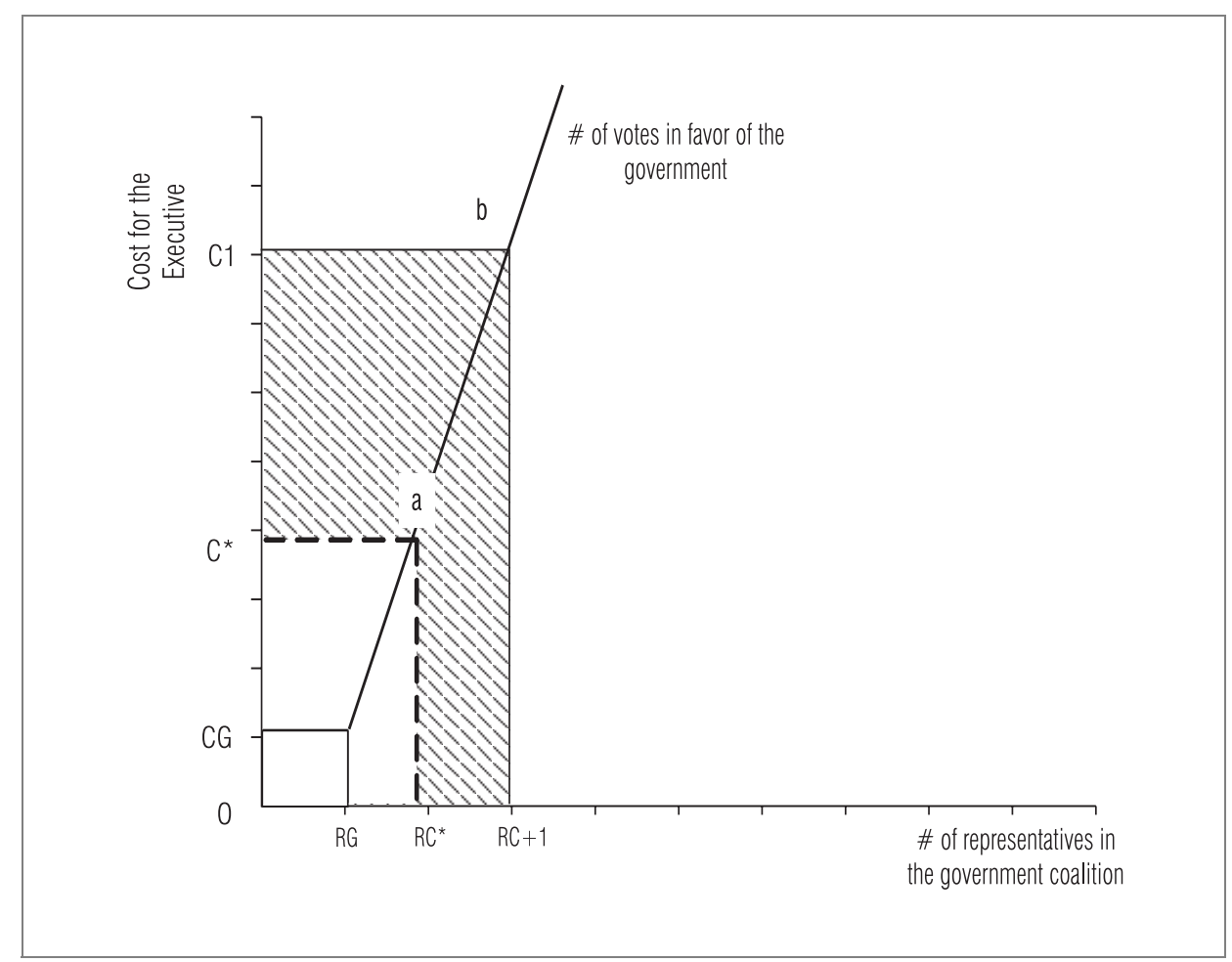

One of the assumptions in the model here presented is that representatives have no perfect information about what happened in the House. In reality one representative has little or no information about how much a second representative is 'charging' the government for his vote. Nevertheless, representatives have the perception of the importance of an amendment. If one could graph the time in the $\mathrm{x}$-axis and the cost of joining the coalition in the $\mathrm{y}$-axis, the process of entering the coalition would assume the shape shown in figure 8 . Therefore, in reality the marginal cost of new members will increase, but not necessarily increase in time, nor in a sequential way. Nevertheless, it seems plausible to assume that the cost of new members for the coalition will increase, and the cost of those last representatives that join the coalition will be higher than that of the first ones. 
Figure 7

Easy to approve amendment

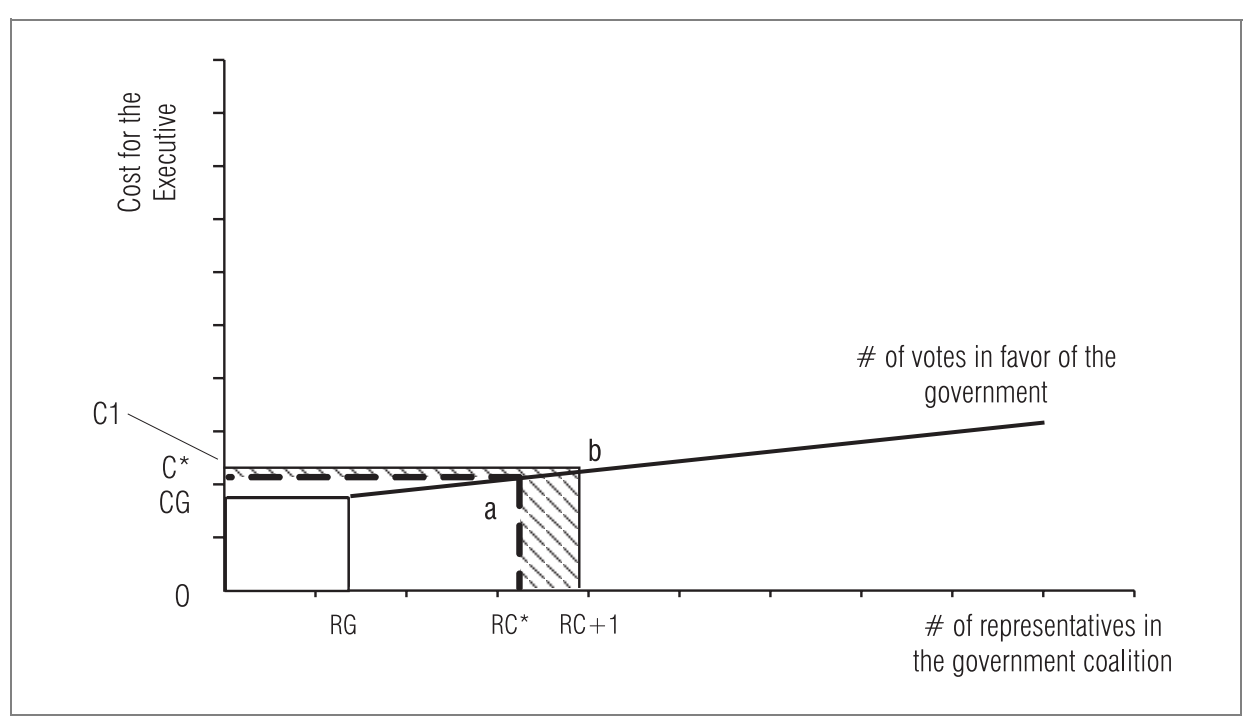

Figure 8

Relationship between cost of joining the governmental coalition and time

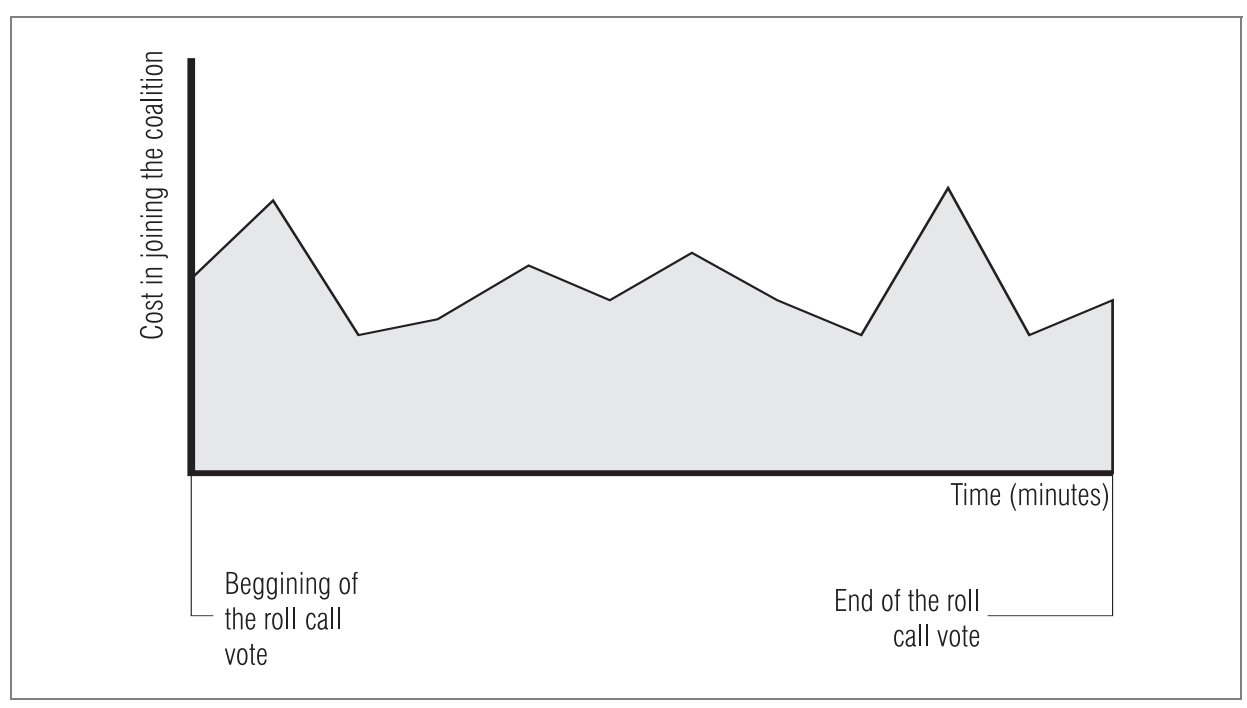

Rap Rio de Janeiro 40(5):865-82, Set./Out. 2006 
Logrolling happened before the roll call vote process started and during the whole process. An empirical fact about that could be the length of each amendment roll call vote. Between 1995 and 1998, the length of each roll call vote varied from 15 minutes to more than one hour and a half.

\section{Conclusion and future research}

This article intended to show how the logrolling process took place in the Brazilian House of Representatives during the period 1995-98, when the approval of constitutional amendments generated great losses to society that were not anticipated by the government. Moreover, the government was unsuccessful in keeping a stable coalition that could give it the necessary support without high-cost trades with representatives. The failure in building the coalition in the beginning of the president's term was aggravated by the trading of votes. According to Mueller (1997), such trade might not produce stable coalitions, nor be free from strategic misrepresentation of preferences - strategic voting.

If fact, the lack of a clear majority party in the House of Representatives, plus the lack of formal punishment for not following the party's vote on roll call, plus the process of trading votes for rewards from the government, was an incentive for representatives not to join, or to leave any formal and stable government coalition. As Arnold (1992) implies, representatives are rational and their main objective is to be reelected. Therefore, the return in trading with the government is much higher than the return in assuming a stable position with it.

An assumption that was taken into consideration in this article was the increase in the marginal cost of representatives entering the governmental coalition. Groseclose and Snyder (1996) present a different view on this topic. According to these authors, the marginal cost in fact decreases when the coalition increases. They assume that two players in the game try to buy votes from Congress members (Groseclose and Snyder, 1996:303):

If the first vote buyer has bribed more than a minimal winning coalition, then the second vote buyer must bribe at least two members of the first vote buyer's coalition. Thus, by bribing more than a minimal coalition, the first vote buyer can decrease the amount of the bribe paid to each member of his original coalition, while keeping constant the amount the second vote buyer must pay to invade successfully. 
While the Groseclose and Snyder model takes into consideration the existence of two competing vote buyers, what actually happened in Brazil was the existence of just one major buyer - the government. Therefore, there was not much space for bargaining between the government and representatives, nor there was a second entity that would compete for the representative vote in an amendment. Moreover, the model presented in this article does not take into consideration that buyers have to move sequentially (Groseclose and Snyder, 1996), but that the logrolling process happened at the same time during the whole vote period.

The major factor that created large government coalitions - and consequently great costs for society - was the uncertainty that the government faced regarding the legislator's preference. This uncertainty was later transformed into sophisticated voting by the legislators who realized the gains that they would have if they logrolled and voted strategically. In their study, Carrubba and Volden (2000) show that even with incentives to create minimum winning coalitions, due to the lack of trust among the legislators, a larger coalition is almost always created in its place.

Additional empirical studies could contribute to create a more robust model about logrolling and government coalition in Brazil. A comparison between the roll call votes for the constitutional amendments and the individual budget amendments approved for the representatives would improve the model. Another set of data that could be used in the analysis is the degree of reelection of the representatives that voted with the government. In this case, one could suppose that those who trade votes with the government would do it to benefit their constituents and, therefore, would have more chances of being reelected. ${ }^{5}$

The model presented in this article seems to describe quite well what happened in Brazil during the approval of the constitutional amendments between 1995 and 1998. However, the model — as other social science models - is a simplistic reproduction of the reality. For instance, it considered that representatives would trade their support directly with the president. In reality, the bargain process was made through party leaders, who would collect single representative's demands and present them as a collective demand to the government. Moreover, the model treated all constitutional amendments equally. In fact, the amendments that dealt with simple issues did not de-

\footnotetext{
${ }^{5}$ In Brazil, representatives are elected for a four-year term without reelection restrictions. The president is also elected for a four-year term with the possibility of one reelection. Senators are elected for an eight-year term with no restrictions regarding reelection.
} 
mand any type of bargain; while those that dealt with public policies demanded negotiations between parties and the government.

Despite these simplifications, the model presented here describes quite well the legislators' behavior and the logrolling process that took place between the Congress and the president in order to approve the constitutional amendments. Moreover, it is believed that although the model deals with a limited period of time, 1995 to 1998, and with only one type of legislative proposal - constitutional amendments - the same logrolling behavior is present in other periods and with other types of legislative proposals.

\section{References}

ARNOLD, R. Douglas. The logic of congressional action. New Haven: Yale University Press, 1992.

ASHER, Herbert B. The learning of legislative norms. In: WEISBERG, Herbert F.; HEBERLIG, Eric S.; CAMPOLI, Lisa M. (Eds.). Classics in congressional politics. New York: Longman, 1999. p. 226-242.

BICKERS, Kenneth; STEIN, Robert. Building majority coalitions for sub-majority benefit distribution. Public Choice, v. 91, p. 229-249, 1997.

CARRUBBA, Clifford J.; VOLDEN, Craig. Coalition politics and logrolling in legislative institutions. American Journal of Political Science, v. 44, n. 2, p. 261-277, 2000.

DAVIDSON, Roger H.; OLESZEK, Walter J. Congress and its members. Washington, DC: CQ Press, 2000.

FAAD, Alexandre. Relações entre o Executivo e Legislativo: a aprovação da reeleição no Congresso Nacional.Thesis (Masters) - UnB, Brasília, 2000.

GROSECLOSE, Tim; SNYDER, James M. Buying supermajorities. The American Political Science Review, v. 90, n. 2, p. 303-315, June 1996.

KOEHLER, David H. Legislative coalition formation: the meaning of minimal winning size with uncertain participation. American Journal of Political Science, v. 19, n. 1, p. 27-39, Feb. 1975.

MARCHI, Scott de; SULLIVAN, Terry. Modeling presidential persuasion: constitutional positions, bargaining, and dead ducks. Chapel Hill: University of North Carolina at Chapel Hill, 1997. 
MATTHEWS, Donald. The folkways of the Senate. In: WEISBERG, Herbert F.; HEBERLIG, Eric S.; CAMPOLI, Lisa M. (Eds.). Classics in congressional politics. New York: Longman, 1999. p. 207-225.

MAYER, Kenneth R.; CANON, David T. The dysfunctional Congress? The individual roots of an institutional dilemma. In: MAISEL, L. Sandy. Dilemmas in American politics. Bolder: Westview Press, 1999.

MUELLER, Dennis C. Public choice II. New York: Cambridge University Press, 1997.

PEREIRA, Carlos; MUELLER, Bernardo. Comportamento estratégico em presidencialismo de coalizão: as relações entre Executivo e Legislativo na elaboração do orçamento brasileiro. Dados — Revista de Ciências Sociais, v. 45, n. 2, p. 265-301, 2002.

SHEPSLE, Kenneth A. On the size of winning coalitions. The American Political Science Review, v. 68, n. 2, p. 505-518, June 1974.

SULLIVAN, Terry. Bargaining with the president: a simple game and new evidence. American Political Science Review, v. 84, p. 1067-1094, Dec. 1990.

WEISBERG, Herbert F.; HEBERLIG, Eric S.; CAMPOLI, Lisa M. (Eds.). Classics in congressional politics. New York: Longman, 1999. 